4. Прохоренко Л.І. Особливості мотиваційного компоненту саморегуляції у молодших школярів із затримкою психічного розвитку в навчальній діяльності / Л. І. Прохоренко // Освіта осіб з особливими потребами: шляхи розбудови. - 2012. - Вип. 3(1). - С. 129-133.

5. Ferguson C.J. The effectiveness of school-based anti-bullying programs: a meta-analytic review / C.J. Ferguson, C. San Miguel, J. C. Kilburn //Crim Justice Rev. -2007. -32(4). - P. 401-414.

6. Xin Z. The Differences of Social Anxiety of Adolescents with Different Sociometric Status / Z. Xin, LChi, B. Liu // Chinese Mental Health Journal. -2004. -Vol 18(4). - P. 231-232.

DOI https://doi.org/10.30525/978-9934-588-80-8-1.34

\title{
ОСОБЛИВОСТІ ОРГАНІЗАЦІЇ КОРЕКЦИЙНОЇ ДОПОМОГИ УЧНЯМ МОЛОДШИХ КЛАСІВ В УМОВАХ ЛОГОПЕДИЧНОГО ПУНКТУ
}

\author{
Бистранівська О. С. \\ викладач-методист \\ Комунальний вищчй навчальний заклад \\ «Уманський гуманітарно-педагогічний коледж імені Т. Г. Шевченка» \\ м. Умань, Черкаська область, Україна
}

Одним із пріоритетних завдань початкової школи $є$ формування у школярів уміння усно і письмово висловлювати свої думки.

У Державному стандарті початкової освіти велика увага надається формуванню комунікативної компетентності та розвитку особистості здобувачів освіти засобами різних видів мовленнєвої діяльності. Особливість мови навчання полягає в тому, що вона $є$ не тільки предметом, а й найважливішим засобом навчання, виховання і розвитку особистості у процесі опанування всіх інших предметів початкової ланки освіти.

Основною із умов успішного навчання молодших школярів $\epsilon$ певний рівень мовленнєвого розвитку дитини, що передбачає сформованість всіх його сторін і сприяє належному оволодінню іншими навчальними дисциплінами. Становлення у дитини всіх психічних функцій, психічних процесів, особистості в цілому неможливе без комунікативно-мовленнєвої взаємодії. 
Сучасні тенденції шкільної освіти потребують від учнів якісних знань, основи яких закладаються на початку шкільного навчання, але рівень сформованості мовленнєвої діяльності першокласників не завжди відповідає вимогам, які пред'являє дітям школа.

А.С. Винокур зазначав, що учні із загальним недорозвитком мовлення відчувають значні труднощі у процесі опанування предметами мовного циклу, та й з інших предметів [2, с. 4].

Є.Ф. Соботович наголошувала, що діти навіть 3 нерізко вираженими порушеннями мовлення, які вступають до загальноосвітніх шкіл, становлять основний контингент невстигаючих учнів (передусім 3 предметів мовного циклу). Усвідомлення власної неповноцінності зазвичай викликає негативні емоційні стани. Усе це ставить під загрозу соціальну значущість особистості і спричинює формування своєрідних психологічних та патопсихологічних особливостей, що потребує спеціальної роботи спрямованої на соціальну адаптацію та реабілітацію дитини [5,c. 2].

В.В. Тарасун зазначає, що причиною труднощів у навчанні дітей $з$ порушеннями мовлення $\epsilon$ недорозвиток базових пізнавальних процесів і функцій.

Такі діти молодшого шкільного віку потребують корекційної допомоги і складають основний контингент логопедичних пунктів при закладах загальної середньої освіти.

Отже, особливо важливим у сучасних умовах розвитку спеціальної освіти $є$ пошук оптимальних шляхів корекції мовлення дітей молодшого шкільного віку.

Як свідчить аналіз науково-теоретичних джерел, питаннями логопедичної допомоги дітям молодшого шкільного віку займалися багато науковців і практиків ( Л. Бартєнєва, Е. Данілавічюте, К. Дяченко, О. Корнєв, Р. Юрова, Н. Гаврилова, Л. Федорович, Л. Сфіменкова, Р. Левіна, Є. Соботович, В. Тарасун, М. Савченко, І. Садовнікова, М.В. Шевченко та ін.).

Проте їх дослідження були спрямовані на вирішення питань подолання порушень мовленнєвого розвитку дітей та попередження труднощів навчання, спираючись на адекватні умови здійснення корекційного впливу. Створення ж корекційно-педагогічного супроводу спільними зусиллями кваліфікованих фахівців 3 метою подолання мовленнєвих недоліків та попередження порушень писемного мовлення залишилися поза увагою.

На думку вітчизняних та зарубіжних науковців (М.К. Шеремет, В.В. Тарасун, Т.Г. Візель та ін.) корекційний вплив повинен бути комплексним. 
При цьому корекцію мовлення та його вдосконалення необхідно розглядати $з$ точки зору формування комунікативної компетентності, що передбачає активне використання рідної мови в різних комунікативних ситуаціях, зокрема в побуті, освітньому процесі тощо.

Мета статті - теоретичне обгрунтування комплексного підходу у корекційній роботі з дітьми молодшого шкільного віку з порушеннями мовлення в умовах логопедичного пункту.

Сутність комплексного підходу у логопедичній роботі полягає у систематизації, регулюванні та координуванні корекційних, розвивальних, виховних, освітніх та оздоровчих стратегії впливу на дитину з порушеннями мовлення. Для того, щоб подолати мовленнєві порушення та сформувати і розвинути мовленнєву діяльність для успішного навчання, необхідна чітка взаємодія всіх учасників освітнього процесу. Основне завдання педагогічної взаємодії у процесі корекційної логопедичної роботи в закладі загальної середньої освіти в умовах логопедичного пункту полягає у створенні продуманої системи корекції мовлення в процесі навчання і виховання, всього життя та діяльності дитини. Тобто потрібне створення творчого об'єднання педагогів та батьків, яке має спільну мету, організовує корекційноосвітнє середовище, комплексний психолого-педагогічний супровід, який стимулює розвиток дітей $з$ порушеннями мовлення. Комплексний підхід створює платформу для ефективної організації та планування корекційно-освітнього процесу і педагогічної взаємодії педагогів та батьків. Водночас розвиток співпраці сприяе більш ефективному супроводу дітей 3 порушеннями мовлення та зростанню ініціативи та відповідальності учасників педагогічної взаємодії .

В науковій літературі $€$ багато напрацювань 3 проблеми спільної роботи та співпраці вчителя-логопеда і сім'ї, яка виховує дитину 3 порушеннями мовлення (Ю. Гаркуша, С. Миронова, Ю. Докучаєва, О. Звєрєва, О. Мастюкова, Т. Ілляшенко, В. Липа та ін.). Зокрема, С. Миронова розглядає мету роботи 3 сім'ями як систему надання батькам кваліфікованої допомоги у вихованні дитини з порушеннями психофізичного розвитку. Визначаючи специфічний зміст і основні завдання цієї роботи, автор охарактеризувала основні види діяльності корекційного педагога у роботі з сім'ями.

Л. Белякова, Т. Візель, О. Лаврова, О. Мастюкова вивчали окремі сторони професійної співпраці логопеда та лікарів, які приймають участь у корекційному процесі. Проблеми лікувально-відновлювальної та корекційно-реабілітаційної роботи та основні шляхи їх вирішення висвітлені у працях В. Селіверстова. Науковець наголошував, що у корекційній роботі з дітьми, які мають порушення мовлення зумовлені 134 
порушеннями нервової системи, необхідна спільна праця логопедів i лікарів.

Науковці С. Шаховська, В. Селіверстов, Н. Крилова, Л. Єфіменкова, I. Садовнікова та ін. займалися питаннями спільної участі у корекційній роботі логопеда і педагогів, психологів дошкільних та шкільних закладів освіти. На думку вчених завдання корекційної роботи логопеда і психолога взаємопов'язані і вирішуються в умовах цілісного підходу до виховання і розвитку психічної діяльності учня. Корекційне навчання спрямоване на загальний розвиток дитини. Таким чином, $\mathrm{i}$ психолог, і логопед, визначаючи основні напрямки своєї роботи (психолог - активізацію інтелектуальної діяльності, логопед - виправлення порушень мовлення та розвиток мовлення), паралельно працюють над розвитком особистості дитини в цілому.

Однак, при наявності великої кількості наукових робіт присвячених проблемам взаємодії учителя-логопеда 3 іншими учасниками корекційно-педагогічного процесу, багато питань комплексної корекційної допомоги дітям молодшого шкільного віку з порушеннями мовлення в умовах логопедичного пункту не знайшли свого вирішення. Не розроблена структура взаємодії між учасниками корекційнопедагогічного супроводу на рівні школи та на рівні регіону. Актуальним питанням залишається розроблення змісту корекційної роботи та завдань для фахівців, які беруть участь у корекційнопедагогічному супроводі дітей молодшого шкільного віку 3 порушеннями мовлення у закладі загальної середньої освіти.

\section{Література:}

1. Державний стандарт початкової освіти. Режим доступу: URL https://zakon.rada.gov.ua/laws/show/87-2018-\%D0\%BF\#Text

2. Винокур А.С. Подолання мовного недорозвинення у дітей молодшого шкільного віку. - К. : «Радянська школа», 1977. - 143 с.

3. Визель Т.Г. Нарушения чтения и письма у детей дошкольного и младшего школьного возраста: учеб.-метод. пособие. - М.: АСТ: Астрель, 2009. - 127 с.

4. Логопедія / [Шеремет М.К., Тарасун В.В., Конопляста С.Ю. та ін.] : за ред. М.К. Шеремет. - [друге видання, перероблене і доповнене] - К.: Видавничий Дім «Слово», 2010. - 678 с.

5. Соботович Є.Ф. Концепція стандарту спеціальної освіти дітей дошкільного віку 3 порушеннями мовленнєвого розвитку / Є.Ф. Соботович // Дефектологія. - 2002. - № 1. - С. 2-7.

6. Хитрюк В.В. Основы дефектологии: учеб.пособие. - Минск: Изд-во Гревцова, 2009. - С. 121. 